\title{
HUBUNGAN PENGETAHUAN, SIKAP, DAN PERILAKU PASIEN HUMAN IMMUNODEFICIENY VIRUS DENGAN PELAYANAN VOLUNTARY COUNSELING AND TESTING DI RSUD DEPOK 2020
}

\author{
Anisa Azhaar Saraswati ${ }^{1}$, Gatot Soeryo Koesomo², Nunuk Nugrohowati ${ }^{3}$ \\ ${ }^{1}$ Program Studi Kedokteran Program Sarjana, FK UPN Veteran Jakarta \\ Email: saraswatianisa@yahoo.co.id \\ ${ }^{2}$ Departemen Ilmu Kesehatan Masyarakat, FK UPN Veteran Jakarta \\ Email: gatot_suryo@yahoo.com \\ ${ }^{3}$ Departemen Ilmu Kesehatan Masyarakat, FK UPN Veteran Jakarta \\ Email: nnugrohowati@gmail.com
}

Masuk : 19-06-2020, revisi: 08-10-2020, diterima untuk diterbitkan : 30-04-2021

\begin{abstract}
ABSTRAK
Penyakit Human Immunodeficiency Virus (HIV) telah menjadi masalah darurat global. Jumlah kasus HIV di Indonesia hingga tahun 2017 mengalami kenaikan, sedangkan jumlah acquired immune deficiency syndrome (AIDS) stabil. Prevalensi ini menunjukkan banyak orang dengan HIV/AIDS (ODHA) yang diketahui statusnya secara dini sehingga perburukan penyakit dapat dicegah. Voluntary counseling and testing (VCT) adalah layanan konseling dan tes HIV yang pelaksanaannya atas inisiatif pasien. Pengetahuan baik mengenai penyakit HIV dan sikap positif terhadap penyakit HIV akan meningkatkan inisiatif melakukan tes HIV, didukung oleh kesadaran perilaku berisiko terinfeksi HIV. Penelitian ini bertujuan mengetahui hubungan antara pengetahuan, sikap, dan perilaku pasien HIV/AIDS dengan pemanfaatan pelayanan VCT serta mengetahui faktor yang paling berpengaruh terhadap pemanfaatan pelayanan VCT. Penelitian ini bersifat analitik observasional dengan desain cross-sectional. Sampel penelitian berupa data primer yaitu pengisian kuesioner oleh 43 pasien HIV. Penelitian dilakukan di RSUD Depok, pemilihan di RSUD Depok karena tingginya prevalensi penyakit HIV di Depok. Teknik pengambilan sampel pada penelitian ini secara consecutive sampling. Penelitian ini membuktikan terdapat hubungan bermakna antara pengetahuan (p-value: 0.008) dan sikap (p-value: 0.000) terhadap pemanfaatan pelayanan VCT. Pemanfaatan pelayanan VCT meningkat dengan pengetahuan baik mengenai HIV dan sikap positif terhadap penyakit HIV.
\end{abstract}

Kata Kunci: Pengetahuan mengenai HIV; Perilaku berisiko HIV; Sikap terhadap penyakit HIV; Voluntary counseling and testing

\begin{abstract}
Human Immunodeficiency Virus (HIV) had become global emergency problem. The number of HIV cases in Indonesia reported until 2017 had increased, while the number of acquired immune deficiency syndrome (AIDS) cases was relatively stable. This prevalence showed that the more HIV status were known at early stage, the possibility of worsening could be reduced. Voluntary counseling and testing (VCT) is an HIV testing and counseling service that is implemented at the initiative of the patients. Good knowledge of HIV and positive attitude towards HIV will increase the initiative to take HIV test, supported by awareness of HIV risk behaviors. The purpose of this study was to determine the relationship between knowledge, attitude, and behavior of PLHIV with the utilization of VCT services and to determine the most influencing factor of VCT service utilization. This study was an analytic observational cross-sectional design. The research samples were from a primary data which were questionnaires filled out by 43 HIV patients. The study was conducted at Depok Regional Public Hospital, the selection of this particular hospital was due to the high prevalence of HIV case in Depok. The sampling technique was consecutive sampling. This study proved that there was a significant relationship between knowledge (p-value: 0.008) and attitude (p-value: 0.000) with the utilization of VCT services. The utilization of VCT services increased with good knowledge of HIV and positive attitude towards HIV disease.
\end{abstract}

Keywords: Attitude towards HIV; HIV risk behavior; Knowledge of HIV; Voluntary counseling and testin. 


\section{PENDAHULUAN}

\section{Latar Belakang}

Penyakit HIV menjadi masalah darurat global. HIV (Human Immunodeficiency Virus) merupakan retrovirus yang menginfeksi sel-sel sistem imun yang mengekspresikan CD4+ (Balasubramaniam et al., 2019). Penemuan terdahulu menyatakan bahwa HIV berkaitan dengan hilangnya sel limfosit T CD4+ dalam tubuh manusia (Schwetz \& Fauci, 2019). Hal ini memudahkan tenaga medis untuk memantau perkembangan penyakit HIV penderita dengan menghitung jumlah sel CD4+ dalam tubuh (Tinarwo et al., 2020). Penyakit HIV memiliki empat stadium, dimana pada stadium akhir penderita akan mengalami berbagai gejala klinis yang disebut sebagai AIDS (Acquired Immunodeficiency Syndrome) (Rastogi et al., 2011). Mayoritas pasien dengan HIV positif akan berkembang menjadi AIDS dalam dekade pertama setelah diagnosis (Poorolajal et al., 2016).

Angka kejadian HIV hingga tahun 2017 mengalami kenaikan setiap tahun, sedangkan angka kejadian AIDS stabil. Prevalensi ini menunjukkan bahwa banyak ODHA yang diketahui statusnya secara dini sehingga perburukan penyakit dapat dicegah dengan pengobatan. Terapi penyakit HIV saat ini menggunakan regimen antiretroviral sebanyak tiga buah obat oral harian yang terdiri dari dua obat nucleoside analogue reverse trancriptase inhibitors dikombinasikan dengan obat ketiga yaitu pilihan antara integrase inhibitor, non-nucleoside reverse transcriptase inhibitor, atau protease inhibitor (Phanuphak \& Gulick, 2020). Sebagai salah satu upaya penanggulangan HIV dan pencegahan AIDS, Komisi Akreditasi Rumah Sakit menetapkan penurunan angka kesakitan HIV/AIDS sebagai salah satu program nasional di dalam Standar Nasional Akreditasi Rumah Sakit (SNARS) Edisi 1 tahun 2018. Salah satu program nasional yang ditetapkan di dalam SNARS adalah penurunan angka kesakitan HIV/AIDS. Program nasional ini berisi layanan-layanan penanggulangan HIV/AIDS, salah satunya adalah dengan melakukan tes HIV.

Tes HIV ditetapkan sebagai prasyarat penegakan diagnosis penyakit HIV. Hasil dari tes HIV dapat menghubungkan orang dengan HIV/AIDS dengan layanan pencegahan dan pengobatan lebih dini. Pemeriksaan HIV yang telah banyak digunakan untuk screening adalah ELISA (enzyme-linked immunosorbent assay) (Mehra et al., 2014). Namun, jumlah penduduk yang melakukan tes sampai saat ini masih tergolong rendah. Hal ini dapat diakibatkan oleh beberapa faktor. Pertama, masyarakat tidak menyadari bahwa HIV mengancam seluruh individu, bukan hanya orang yang berperilaku berisiko. Kedua, stigma negatif yang melekat pada penyakit HIV begitu kuat. Untuk menghindari hal-hal tersebut, pemerintah menetapkan program Voluntary Counseling and Testing (VCT) di dalam SNARS Edisi 1 tahun 2018.

VCT memainkan peran penting dalam tanggapan dunia terhadap pandemi HIV/AIDS, bertujuan untuk meningkatkan pengobatan dan perawatan pasien (Duflo et al., 2019). Layanan ini menyediakan tes HIV sukarela dan menawarkan informasi mengenai penyakit HIV, termasuk cara penularan, pencegahan, pengobatan, dan penilaian risiko menularkan kepada orang lain (Sargolzaei et al., 2018). Selain menyediakan layanan tes HIV, VCT juga menyediakan layanan konseling yang mencakup tiga komponen yaitu dukungan emosional, dukungan edukasi, dan penilaian risiko (Taquette et al., 2017). Individu yang memiliki pengetahuan baik mengenai penyakit HIV serta sikap yang positif terhadap penyakit HIV akan cenderung meningkatkan inisiatif individu tersebut untuk melakukan pemeriksaan HIV/AIDS dengan didukung oleh kesadaran perilaku yang berisiko terinfeksi HIV. Sikap yang positif terhadap penyakit HIV ditunjukkan dengan kesediaan pasien untuk berperilaku seks yang aman dengan pasangan, bersedia mencari akses informasi pelayanan kesehatan yang berkaitan dengan penyakit HIV, 
serta berkeinginan untuk mengubah masa depan menjadi lebih baik. Perilaku yang berisiko terinfeksi HIV meliputi kebiasaan berhubungan seks dengan teman, dengan pasangan, dengan sesama jenis, dengan Pekerja Seks Komersial, serta penggunaan narkoba suntik.

Penelitian sebelumnya yang dilakukan oleh Pratiwi dan Rosida memberikan hasil terdapat hubungan antara pengetahuan dengan pemanfaatan layanan VCT (2018). Penelitian yang dilakukan Ria Puspitasari memberikan hasil terdapat hubungan antara sikap dengan pemanfaatan layanan VCT (2016). Penelitian yang dilakukan Syahrir, dkk memberikan hasil terdapat hubungan antara pengetahuan dengan pemanfaatan layanan VCT dan tidak ada hubungan antara sikap dengan pemanfaatan layanan VCT (2014). Penelitian-penelitian terdahulu ini tidak memberikan hasil selaras.

Angka kasus HIV di Kota Depok meningkat setiap tahunnya. Jumlah kasus penyakit HIV yang tinggi di wilayah Kota Depok tidak seimbang dengan jumlah klinik VCT yang tersedia. Penelitian ini dapat memberikan informasi mengenai apakah ODHA di wilayah Kota Depok memanfaatkan klinik VCT dengan baik walaupun jumlah yang tersedia masih tergolong sedikit. Pemanfaatan klinik VCT yang baik berarti pasien menggunakan seluruh tahapan VCT sehingga memberikan hasil yang maksimal berupa pengobatan, perbaikan gaya hidup, serta pencegahan terjadinya perburukan. Berdasarkan latar belakang tersebut maka peneliti merasa tertarik untuk melakukan penelitian mengenai hubungan pengetahuan, sikap, dan perilaku pasien HIV/AIDS dengan pelayanan VCT di RSUD Depok tahun 2020.

\section{Rumusan Masalah}

Angka kasus HIV di Kota Depok meningkat setiap tahun. Deteksi HIV dapat dilakukan dengan Voluntary Counseling and Testing (VCT) atas inisiatif individu yang bersangkutan. Inisiatif ini diduga dapat ditingkatkan dengan pengetahuan baik mengenai HIV serta sikap positif terhadap penyakit HIV/AIDS dengan didukung oleh kesadaran perilaku berisiko terinfeksi HIV. Penelitian terdahulu tidak memberikan hasil yang selaras mengenai hubungan antara faktorfaktor tersebut dengan pelayanan VCT. Berdasarkan hal tersebut diatas maka rumusan masalah penelitian ini adalah apakah terdapat hubungan pengetahuan, sikap, dan perilaku pasien HIV/AIDS dengan pelayanan Voluntary Counseling and Testing (VCT) di RSUD Depok tahun 2020.

\section{METODE PENELITIAN Desain penelitian}

Jenis penelitian yang digunakan adalah analitik observasional dengan desain penelitian crosssectional. Penelitian ini dilakukan untuk mengetahui adanya hubungan yang bermakna antara pengetahuan mengenai HIV, sikap terhadap penyakit HIV, dan perilaku berisiko HIV dengan pemanfaatan pelayanan VCT di Rumah Sakit Umum Daerah Kota Depok tahun 2020.

\section{Populasi dan sampel}

Populasi dalam penelitian ini adalah pasien di Rumah Sakit Umum Daerah Kota Depok tahun 2020. Sampel dalam penelitian ini adalah pasien HIV di Rumah Sakit Umum Daerah Kota Depok tahun 2020 yang memenuhi kriteria inklusi dan eksklusi. Kriteria inklusi penelitian ini adalah pasien HIV yang menggunakan layanan VCT, berusia di atas 17 tahun, dapat membaca dan menulis, serta kondisi pasien memungkinkan untuk mengisi kuesioner. Kriteria eksklusi penelitian ini adalah pasien yang tidak menderita penyakit bukan bawaan HIV, pasien yang tidak mengisi kuesioner secara lengkap, dan pasien yang tidak bersedia menjadi subjek penelitian. 


\section{Pengambilan sampel}

Teknik pengambilan sampel yang digunakan dalam penelitian ini adalah teknik consecutive sampling. Subjek yang diteliti adalah pasien HIV di Rumah Sakit Umum Daerah Kota Depok yang memenuhi kriteria sampel penelitian.

\section{Pengumpulan data}

Jenis data yang digunakan dalam penelitian ini adalah data primer dan sekunder. Data primer pada penelitian ini didapat dari kuesioner yang telah diisi oleh pasien HIV di poli VCT Rumah Sakit Umum Daerah Kota Depok. Kuesioner yang digunakan berisikan pertanyaan-pertanyaan seputar pengetahuan, sikap, dan perilaku mengenai penyakit HIV dan pelayanan VCT. Kuesioner diambil dari penelitian sebelumnya dan sudah lolos uji validitas dan reliabilitas. Kuesioner yang telah diisi kemudian diolah dengan menggunakan aplikasi uji statistik SPSS. Data sekunder pada penelitian ini berupa profil Rumah Sakit Umum Daerah Kota Depok dan catatan jumlah kunjungan pasien poli VCT tahun 2019.

\section{Prosedur penelitian}

Peneliti mengajukan surat permohonan izin penelitian kepada Direktur Rumah Sakit Umum Daerah Kota Depok dan bekerjasama dengan poli VCT Rumah Sakit Umum Daerah Kota Depok untuk memberian kuesioner kepada pasien HIV yang memenuhi kriteria inklusi dan eksklusi.

\section{HASIL DAN PEMBAHASAN}

\section{Karakteristik responden}

Karakteristik responden meliputi usia, jenis kelamin, status perkawinan, dan pendidikan terakhir. Sebagian besar responden berusia $31-40$ tahun yaitu sebanyak 24 orang (55.8\%). Berdasarkan data jenis kelamin, sebagian besar responden berjenis kelamin laki-laki yaitu sebanyak 37 orang $(86 \%)$. Berdasarkan data status perkawinan, sebagian besar responden memiliki status sudah menikah atau kawin yaitu sebanyak 22 orang (51.2\%). Berdasarkan data pendidikan terakhir, mayoritas responden adalah lulusan SLTA/sederajat yaitu sebanyak 28 orang (65.1\%). Karakteristik responden dapat dilihat pada Tabel 1.

Tabel 1. Karakteristik Responden Penelitian

Sumber tabel: Data Primer, 2020

\begin{tabular}{lcc}
\hline Usia & $\mathbf{N}$ & $\mathbf{\%}$ \\
\hline $21-30$ tahun & 11 & $25.6 \%$ \\
$31-40$ tahun & 24 & $55.8 \%$ \\
$41-50$ tahun & 8 & $18.6 \%$ \\
\hline Jenis Kelamin & & \\
\hline Laki-laki & 37 & $86 \%$ \\
Perempuan & 6 & $14 \%$ \\
\hline Status Perkawinan & & \\
\hline Kawin & 22 & $51.2 \%$ \\
Belum kawin & 19 & $44.1 \%$ \\
Cerai & 2 & $4.7 \%$ \\
\hline Pendidikan Terakhir & & \\
\hline SLTP/Sederajat & 6 & $14 \%$ \\
SLTA/Sederajat & 28 & $65.1 \%$ \\
Strata I & 9 & $20.9 \%$ \\
\hline Total & $\mathbf{4 3}$ & $\mathbf{1 0 0 \%}$ \\
\hline
\end{tabular}




\section{Hasil Analisis Univariat}

Gambaran Pengetahuan mengenai HIV, Sikap terhadap Penyakit HIV, Perilaku Berisiko HIV, dan Pemanfaatan Pelayanan VCT pada Responden Pasien HIV di Rumah Sakit Umum Daerah Kota Depok

Hasil analisis univariat pada penelitian ini dapat dilihat pada Tabel 2. Data menunjukkan bahwa mayoritas responden memiliki pengetahuan mengenai penyakit HIV yang tergolong baik yaitu sejumlah 34 responden $(79.1 \%)$ dan responden yang memiliki pengetahuan buruk berjumlah 9 orang (20.9\%). Mayoritas responden memiliki sikap terhadap penyakit HIV yang tergolong positif yaitu sejumlah 35 responden (81.4\%), sedangkan responden yang memiliki sikap negatif sejumlah 8 responden (18.6\%). Sebagian besar responden memiliki perilaku yang tergolong tidak berisiko tertular HIV yaitu sebanyak 31 responden $(72.1 \%)$, sedangkan responden yang memiliki perilaku berisiko sejumlah 12 responden $(27.9 \%)$. Mayoritas responden memanfaatkan pelayanan VCT dengan baik yaitu sejumlah 31 responden $(72.1 \%)$, sedangkan responden yang memanfaatkan pelayanan VCT dengan buruk sebanyak 12 orang (27.9\%).

Tabel 2. Distribusi Pengetahuan mengenai HIV, Sikap terhadap Penyakit HIV, Perilaku Berisiko HIV, dan Pemanfaatan Pelayanan VCT pada Responden Pasien HIV di Rumah Sakit Umum

Daerah Kota Depok

Sumber tabel: Data Primer, 2020

\begin{tabular}{lcc}
\hline Pengetahuan mengenai HIV & N & \% \\
\hline Baik & 34 & $79.1 \%$ \\
Buruk & 9 & $20.9 \%$ \\
\hline Sikap terhadap penyakit HIV & & \\
\hline Positif & 35 & $81.4 \%$ \\
Negatif & 8 & $18.6 \%$ \\
\hline Perilaku Berisiko HIV & & \\
\hline Tidak Berisiko & 31 & $72.1 \%$ \\
Berisiko & 12 & $27.9 \%$ \\
\hline Pemanfaatan Pelayanan HIV & & \\
\hline Baik & 31 & $72.1 \%$ \\
Buruk & 12 & $27.9 \%$ \\
\hline Total & 43 & $100 \%$ \\
\hline
\end{tabular}

\section{Hasil Analisis Bivariat}

Hubungan antara Pengetahuan dengan Pelayanan VCT di Rumah Sakit Umum Daerah Kota Depok

Hubungan pengetahuan tentang HIV dengan pemanfaatan pelayanan VCT dapat dilihat pada Tabel 3.

Tabel 3. Hubungan antara Pengetahuan dengan Pelayanan VCT

Sumber tabel: Data Primer, 2020

\begin{tabular}{lcccccc}
\hline \multirow{2}{*}{$\begin{array}{l}\text { Pengetahuan } \\
\text { HIV }\end{array}$} & \multicolumn{4}{c}{$\begin{array}{c}\text { Pemanfaatan Pelayanan } \\
\text { VCT }\end{array}$} & \multirow{2}{*}{$\begin{array}{c}\text { Total } \\
\text { (N) }\end{array}$} & P-value \\
\cline { 2 - 5 } & \multicolumn{2}{c}{ Baik } & \multicolumn{2}{c}{ Buruk } & & \\
\cline { 2 - 5 } & $\mathbf{N}$ & $\mathbf{\%}$ & $\mathbf{N}$ & $\mathbf{\%}$ & & \\
\hline Baik & 28 & $65.1 \%$ & 6 & $14 \%$ & 34 & 0.008 \\
Buruk & 3 & $7 \%$ & 6 & $14 \%$ & 9 & \\
\hline Total & $\mathbf{3 1}$ & $\mathbf{7 2 . 1 \%}$ & $\mathbf{1 2}$ & $\mathbf{2 7 . 9 \%}$ & $\mathbf{4 3}$ & \\
\hline
\end{tabular}

Jenis Uji Statistik: Fisher's Exact Test 
Tabel 3 menunjukkan bahwa mayoritas responden yang memiliki pengetahuan baik tentang HIV memiliki kecenderungan untuk memanfaatkan layanan VCT dengan baik yaitu sejumlah 28 responden $(65.1 \%)$. Uji Fisher's memberikan hasil terdapat hubungan yang signifikan antara pengetahuan tentang HIV dengan pemanfaatan pelayanan VCT dengan $p$-value $0.008(\mathrm{p}<0.05)$.

\section{Hubungan antara Sikap dengan Pelayanan VCT di Rumah Sakit Umum Daerah Kota Depok \\ Hubungan sikap terhadap HIV dengan pemanfaatan pelayanan VCT dapat dilihat pada Tabel 4.}

Tabel 4. Hubungan antara Sikap dengan Pelayanan VCT

Sumber tabel: Data Primer, 2020

\begin{tabular}{lcccccc}
\hline $\begin{array}{l}\text { Sikap } \\
\text { terhadap }\end{array}$ HIV & \multicolumn{4}{c}{$\begin{array}{c}\text { Pemanfaatan Pelayanan } \\
\text { VCT }\end{array}$} & $\begin{array}{c}\text { Total } \\
\text { (N) }\end{array}$ & $\begin{array}{r}\text { P-value } \\
\end{array}$ \\
\cline { 2 - 5 } & \multicolumn{2}{c}{ Baik } & \multicolumn{2}{c}{ Buruk } & & \\
\cline { 2 - 5 } & $\mathbf{N}$ & $\%$ & $\mathbf{N}$ & $\mathbf{\%}$ & & \\
\hline Positif & 30 & $69.8 \%$ & 5 & $11.6 \%$ & 35 & 0.000 \\
Negatif & 1 & $2.3 \%$ & 7 & $16.3 \%$ & 8 & \\
\hline Total & $\mathbf{3 1}$ & $\mathbf{7 2 . 1 \%}$ & $\mathbf{1 2}$ & $\mathbf{2 7 . 9 \%}$ & $\mathbf{4 3}$ & \\
\hline
\end{tabular}

Jenis Uji Statistik: Fisher's Exact Test

Tabel 4 menunjukkan bahwa mayoritas responden yang memiliki sikap positif terhadap penyakit HIV memiliki kecenderungan untuk memanfaatkan layanan VCT dengan baik yaitu sejumlah 30 responden $(69.8 \%)$. Uji Fisher's memberikan hasil terdapat hubungan yang signifikan antara sikap terhadap penyakit HIV dengan pemanfaatan pelayanan VCT dengan p-value 0.000 ( $\mathrm{p}$ $<0.05)$.

\section{Hubungan antara Perilaku dengan Pelayanan VCT di Rumah Sakit Umum Daerah Kota Depok}

Hubungan perilaku berisiko tertular HIV dengan pemanfaatan pelayanan VCT dapat dilihat pada Tabel 5.

Tabel 5. Hubungan antara Perilaku dengan Pelayanan VCT

Sumber tabel: Data Primer, 2020

\begin{tabular}{lcccccc}
\hline \multirow{2}{*}{$\begin{array}{l}\text { Perilaku } \\
\text { berisiko }\end{array}$} & \multicolumn{4}{c}{ Pemanfaatan Pelayanan } & $\begin{array}{c}\text { Total } \\
\text { HIV }\end{array}$ & \multicolumn{4}{c}{ VCT } & P-value \\
\cline { 2 - 5 } & \multicolumn{2}{c}{ Baik } & \multicolumn{2}{c}{ Buruk } & \\
\cline { 2 - 5 } & $\mathbf{N}$ & $\%$ & $\mathbf{N}$ & $\%$ & & \\
\hline $\begin{array}{l}\text { Tidak } \\
\text { berisiko }\end{array}$ & 21 & $48.8 \%$ & 10 & $23.3 \%$ & 31 & 0.456 \\
Berisiko & 10 & $23.3 \%$ & 2 & $4.7 \%$ & 12 & \\
\hline Total & $\mathbf{3 1}$ & $\mathbf{7 2 . 1 \%}$ & $\mathbf{1 2}$ & $\mathbf{2 7 . 9 \%}$ & $\mathbf{4 3}$ & \\
\hline
\end{tabular}

Jenis Uji Statistik: Fisher's Exact Test 
Tabel 5 menunjukkan bahwa mayoritas responden yang berperilaku tidak berisiko tertular HIV memiliki kecenderungan untuk memanfaatkan layanan VCT dengan baik yaitu sejumlah 21 responden (48.8\%). Uji Fisher's memberikan hasil tidak terdapat hubungan bermakna antara perilaku berisiko tertular HIV dengan pemanfaatan pelayanan VCT dengan p-value 0.456 (p $>0.05)$.

\section{Hasil Analisis Multivariat}

Analisis multivariat dalam penelitian ini digunakan untuk menentukan faktor yang paling berpengaruh terhadap pemanfaatan layanan VCT oleh pasien HIV di Rumah Sakit Umum Daerah Kota Depok. Hasil analisis multivariat dapat dilihat pada Tabel 6.

Tabel 6. Hasil Analisis Multivariat

Sumber tabel: Data Primer, 2020

\begin{tabular}{lccc}
\hline \multicolumn{1}{c}{ Variabel } & Koefisien B & P-value & OR (95\% CI) \\
\hline Pengetahuan mengenai HIV & 1.698 & 0.055 & $7.154(1.806-48.241)$ \\
\hline Sikap terhadap penyakit HIV & 3.557 & 0.004 & $35.052(4.214-418.604)$ \\
\hline
\end{tabular}

Jenis Uji Statistik: Uji regresi berganda

Berdasarkan hasil analisis uji statistik menggunakan regresi logistik dengan derajat kepercayaan $95 \%$, didapatkan bahwa variabel sikap terhadap penyakit HIV memiliki $p$-value $0.004(\mathrm{p}<0.05)$. Variabel ini memiliki nilai odds ratio (OR) sebesar 35.052.

\section{Pembahasan}

Pengetahuan mengenai HIV dalam penelitian ini didasarkan atas beberapa pertanyaan berupa definisi, penyebab, cara penularan, penanganan, biaya pengobatan, dan perjalanan penyakit. Tabel 2 menunjukkan bahwa mayoritas responden memiliki pengetahuan baik mengenai penyakit HIV yaitu sebanyak 34 orang responden (79.1\%).

Sikap terhadap penyakit HIV dalam penelitian ini didasarkan atas beberapa pertanyaan berupa kesediaannya untuk berperilaku seks yang aman dengan pasangan, bersedia mencari akses informasi pelayanan kesehatan yang berkaitan dengan penyakit HIV dan infeksi menular seksual lainnya, serta berkeinginan untuk mengubah masa depan menjadi lebih baik. Tabel 2 menunjukkan bahwa mayoritas responden memiliki sikap positif terhadap penyakit HIV yaitu sebanyak 35 responden $(81.4 \%)$.

Perilaku berisiko tertular HIV dalam penelitian ini didasarkan beberapa pertanyaan mengenai kebiasaan berhubungan seks dengan teman, dengan pasangan, dengan sesama jenis, dengan Pekerja Seks Komersial, serta penggunaan narkoba suntik. Tabel 2 menunjukkan bahwa mayoritas responden memiliki perilaku tidak berisiko tertular HIV yaitu sebanyak 31 responden $(72.1 \%)$

Pemanfaatan layanan VCT yang baik berarti pasien menggunakan seluruh tahapan VCT. Sebaliknya, pemanfaatan layanan VCT yang buruk berarti pasien hanya menggunakan sebagian tahap saja (Syahrir et al., 2014). Pemanfaatan layanan VCT yang baik akan memberikan hasil yang baik bagi kesehatan individu tersebut, yaitu dengan pengobatan yang maksimal, perbaikan gaya hidup serta pencegahan terjadinya perburukan. Tabel 2 menunjukkan bahwa mayoritas responden memanfaatkan pelayanan VCT dengan baik yaitu sebanyak 31 responden $(72.1 \%)$. 
Hasil analisis menunjukkan terdapat hubungan yang signifikan antara pengetahuan mengenai HIV dengan pemanfaatan pelayanan VCT. Hal tersebut sesuai dengan teori bahwa pemanfaatan layanan VCT dapat dipengaruhi oleh tingkat pengetahuan yang dimiliki seorang individu (Syahrir et al., 2014). Secara teoritis, seseorang akan memanfaatkan suatu pelayanan kesehatan jika didukung dengan pengetahuan yang baik mengenai pelayanan kesehatan tersebut dan penyakit yang bersangkutan. Hasil penelitian ini sejalan dengan studi yang dilakukan Devi Pratiwi dan Luluk Rosida (2018) di Yogyakarta yang memberikan hasil bahwa terdapat hubungan antara pengetahuan dengan pelayanan VCT dengan $p$-value 0.002 ( $\mathrm{p}<0.05)$. Hasil penelitian ini juga sejalan dengan studi yang dilakukan Ria Puspitasari (2016) di Banjarsari, Surakarta yang memberikan hasil terdapat hubungan antara pengetahuan dengan kesediaan melakukan VCT dengan p-value 0.000 (p <0.05). Hasil penelitian ini juga sejalan dengan studi yang dilakukan Syahrir, dkk (2014) di Makassar yang menyatakan bahwa terdapat hubungan antara pengetahuan dengan pemanfaatan layanan VCT dengan $p$-value 0.049 ( $\mathrm{p}<0.05)$.

Hasil analisis menunjukkan terdapat hubungan yang signifikan antara sikap terhadap penyakit HIV dengan pemanfaatan pelayanan VCT. Hal tersebut sesuai dengan teori bahwa pelayanan VCT dapat dipengaruhi oleh sikap individu tersebut (Syahrir et al., 2014). Responden yang memiliki sikap positif terhadap penyakit HIV pada penelitian ini cenderung memanfaatkan layanan VCT dengan baik karena mereka berpendapat bahwa dengan rutin melakukan layanan VCT, mereka dapat mengaplikasikan perilaku seksual yang aman dengan pasangan mereka. Mereka berkeyakinan akan terkena AIDS jika tidak rutin menggunakan layanan VCT. Mereka juga berpendapat bahwa dengan melakukan VCT secara rutin mereka menjadi lebih banyak tahu tentang perburukan penyakit HIV dan infeksi menular seksual lainnya. Hasil penelitian ini sejalan dengan studi yang dilakukan Ria Puspitasari (2016) di Banjarsari, Surakarta yang memberikan hasil terdapat hubungan antara sikap dengan kesediaan melakukan VCT dengan pvalue 0.034 ( $\mathrm{p}<0.05$ ) namun hasil penelitian ini tidak sejalan dengan studi yang dilakukan Syahrir, dkk (2014) di Makassar yang menyatakan bahwa tidak terdapat hubungan antara sikap dengan pemanfaatan VCT dengan p-value 0.555 ( $\mathrm{p}>0.05$ ).

Analisis hubungan perilaku berisiko HIV dengan pemanfaatan pelayanan VCT menggunakan analisis bivariat memberikan hasil tidak terdapat hubungan antara kedua variabel. Pada penelitian ini mayoritas responden yang menggunakan layanan VCT dengan baik memiliki perilaku tidak berisiko yaitu sebanyak 21 orang responden $(48.8 \%)$.

Hasil analisis menunjukkan bahwa sikap terhadap penyakit HIV memiliki pengaruh yang lebih kuat dibandingkan pengetahuan mengenai HIV sehingga sikap terhadap penyakit HIV ditetapkan sebagai faktor yang paling memengaruhi pemanfaatan pelayanan VCT. Kekuatan hubungan dapat dilihat dari nilai OR yaitu sebesar 35.052 sehingga dapat disimpulkan bahwa pasien HIV yang memiliki sikap positif terhadap penyakit HIV 35.052 kali lebih cenderung memanfaatkan pelayanan VCT dengan baik dibandingkan dengan pasien yang memiliki sikap negatif.

\section{KESIMPULAN DAN SARAN}

Berdasarkan hasil penelitian dan pembahasan, maka dapat disimpulkan bahwa responden penelitian berjumlah 43 orang yang memiliki kisaran usia di antara 21-50 tahun, terdiri dari 37 orang laki-laki dan 6 orang perempuan, dengan data status perkawinan 22 orang berstatus sudah kawin, 19 orang belum kawin dan 2 orang berstatus cerai, dan data pendidikan terakhir yaitu 28 orang merupakan lulusan SLTA/sederajat, 9 orang lulusan Strata I, dan 6 orang lulusan SLTP/sederajat. Mayoritas responden memiliki pengetahuan mengenai penyakit HIV yang tergolong baik yaitu sejumlah 34 responden (79.1\%). Mayoritas responden memiliki sikap positif 
terhadap penyakit HIV yaitu sejumlah 35 responden $(81.4 \%)$. Mayoritas responden memiliki perilaku yang tergolong tidak berisiko tertular HIV yaitu sebanyak 31 responden (72.1\%). Mayoritas responden memanfaatkan pelayanan VCT dengan baik yaitu sejumlah 31 responden (72.1\%). Penelitian ini membuktikan terdapat hubungan bermakna antara pengetahuan mengenai HIV dan sikap terhadap penyakit HIV dengan pemanfaatan layanan VCT. Berdasarkan hasil analisis multivariat, sikap terhadap penyakit HIV merupakan faktor yang paling berpengaruh terhadap pemanfaatan pelayanan VCT.

\section{REFERENSI}

Balasubramaniam, M, Pandhare, J, Dash, C. (2019). Immune Control of HIV. Journal of Life Sciences, 1, 4-36.

Duflo, E, Dupas, P, Ginn, F, Barasa, G, Baraza, M, Pouliquen, V, Sharma, V. (2019). HIV prevention among youth: A randomized controlled trial of voluntary counseling and testing for HIV and male condom distribution in rural Kenya. Public Library of Science, 14, 1-20.

Mehra, B, Bahnu, S, Bhalla, P, Rawat, D. (2014). Rapid Tests versus ELISA for Screening of HIV Infection: Our Experience from a Voluntary Counseling and Testing Facility of a Tertiary Care Centre in North India. ISRN AIDS, 2014, 1-5.

Phanuphak, N. \& Gulick, R. (2020). HIV treatment and prevention 2019 current standards of care. Current Opinion in HIV and AIDS, 15, 4-12.

Poorolajal, J, Hooshmand, E, Mahjub, H, Esmailnasab, N, Jenabi, E. (2016). Survival rate of AIDS disease and mortality in HIV-infected patients: a meta-analysis. The Royal Society for Public Health Journal, 139, 3-12.

Puspitasari, R. (2016). Hubungan Pengetahuan, Sikap, tentang HIV/AIDS dan VCT serta Peran Petugas dengan Kesediaan Melakukan VCT pada Wanita Pekerja Seks di Wilayah Gilingan Kecamatan Banjarsari Surakarta. Skripsi. Universitas Muhammadiyah Surakarta.

Rastogi, S, Agrahari, S, Singh, U, Singh, A, Verma, A. (2011). Clinical Stage of HIV. Biolixir Amity University Journal, 1, 29-31.

Rosida, L. \& Pratiwi, D. (2018). Hubungan Pengetahuan tentang HIV/AIDS dengan Pemanfaatan Pelayanan VCT di Puskesmas Gedongtengen Yogyakarta. Jurnal Kebidanan, 7, 4-5.

Rosida, L., \& Pratiwi, D. (2018). Hubungan Pengetahuan Tentang HIV/AIDS dengan Pemanfaatan Pelayanan VCT Di Puskesmas Gedongtengen Yogyakarta. Jurnal Kebidanan, 7(1), 23-27. doi:https://doi.org/10.26714/jk.7.1.2018.23-27

Sargolzaei N, Mohebi M D, Hosaini S S, Farzad Z.(2018). Psychological Well-Being and Social Support in Patients with HIV/AIDS in South-East Iran, Int J High Risk Behav Addict. 7(4):e67472. doi: 10.5812/ijhrba.67472.

Schwetz, TA. \& Fauci, AS. (2019). The Extended Impact of Human Immunodeficiency Virus/AIDS Research. The Journal of Infectious Diseases, 219, 6-9.

Syahrir, W, Amiruddin, R, Wahiduddin. (2014). Faktor Yang Berhubungan dengan Pemanfaatan Klinik Voluntary Counseling and Testing (VCT) di Puskesmas Kota Makassar. Tesis. Universitas Hasanuddin. 
Taquette, SR, Rodrigues, AO, Bortolotti, LR. (2017). Perception of pre- and post-HIV test counseling among patients diagnosed with aids in adolescence HIV test counseling for adolescents. Ciência \& Saúde Coletiva, 22, 23-30.

Tinarwo, P, Zewotir, T, North, D. (2020). Trends and Adaptive Optimal Set Points of CD4+ Count Clinical Covariates at Each Phase of the HIV Disease Progression. Hindawi AIDS Research and Treatment, 2020, 1-14. 